\title{
Genetic and environmental effects on sexual precocity traits in Nellore cattle
}

\author{
Sarah Laguna Meirelles ${ }^{1}$, Ana Carolina Espasandin² ${ }^{2}$, Maira Mattar ${ }^{1}$, Sandra Aidar de Queiroz ${ }^{4}$ \\ 1 Doutoranda do Programa de Pós-Graduação em Zootecnia - FCAV - Unesp - Jaboticabal - SP. \\ 2 Depto. de Prod. Animal y Pasturas - Universidad de la República O. del Uruguay - Faculdad de Agronomía. \\ ${ }^{3}$ Departamento de Zootecnia - FCAV - Unesp - Jaboticabal - SP. Bolsista do CNPq.
}

ABSTRACT - The objective of this study was to estimate the heritability of probability of early pregnancy (PEP) and scrotal circumference (SC) and the genetic correlation between these traits in Nellore cattle. PEP records from 11,696 Nellore females born between 1983 and 2001 were analyzed. PEP was assumed to be one for females that effectively bred in the herd (19.84\%) and zero for those discarded before first calving (80.16\%). The model used to study PEP included the effects of contemporary group, age of dam at calving and heifer weaning age, direct additive genetic effects, and residual effects. For SC, 9335 records were analyzed considering the effect of contemporary group, direct additive genetic effects and residual effects. Covariance components were estimated by Gibbs sampling applied to a two-trait sire model, using a threshold model for PEP and a linear model for SC. Estimated mean heritability was $0.47 \pm 0.05$ for PEP and $0.27 \pm 0.03$ for SC, and the genetic correlation between traits was $0.12 \pm 0.20$. These results indicated the existence of additive genetic variation for PEP and this trait should therefore respond to selection. The estimated genetic correlation between PEP and SC indicated a low, but favorable, association. Thus, SC might be used together with PEP in genetic evaluations of sexual precocity. This procedure would increase the accuracy of predicting expected progeny differences for PEP.

Key Words: beef cattle, early pregnancy, scrotal circumference, threshold trait

\section{Efeitos genéticos e ambientais sobre características de precocidade sexual em bovinos Nelore}

RESUMO - O objetivo neste trabalho foi estimar a herdabilidade das características probabilidade de prenhez precoce (PPP) e perímetro escrotal (PE) de animais da raça Nelore e a correlação genética entre essas características. Foram analisados dados de probabilidade de prenhez precoce de 11.696 fêmeas da raça Nelore nascidas entre 1983 e 2001 . A probabilidade de prenhez precoce assumiu o valor 1 para fêmeas que efetivamente reproduziram no rebanho (19,84\%) e zero para aquelas descartadas antes do primeiro parto (80,16\%). O modelo para PPP incluiu os efeitos de grupo de contemporâneos, classe de idade da mãe e classe de idade à desmama da novilha, efeitos genéticos aditivos direto e residual. Foram analisadas 9.335 informações de perímetro escrotal, considerando os efeitos de grupo de contemporâneos, genético aditivo direto e residual. Os componentes de covariância foram estimados usando amostragem de Gibbs, em análise bicaracterística, utilizando-se modelo touro; a PPP, por modelo de limiar; e o perímetro escrotal, por modelo linear. As análises forneceram estimativas médias de herdabilidade iguais a $0,47 \pm 0,05$ e $0,27 \pm 0,03$ para PPP e PE, respectivamente, e de $0,12 \pm 0,20$ para a correlação genética entre essas características. Esses resultados indicam que existe variação genética aditiva para PPP e, portanto, essa característica deve responder à seleção. A correlação genética estimada entre PPP e PE indica associação baixa entre essas características, porém favorável. Assim, pode-se utilizar o perímetro escrotal juntamente com a PPP nas avaliações genéticas da precocidade sexual, um procedimento aumentaria a acurácia da predição da DEP (diferença esperada na progênie) da PPP.

Palavras-chave: característica de limar, gado de corte, perímetro escrotal, precocidade sexual

\section{Introduction}

Although genetic breeding programs of cattle in Brazil have emphasized weight performance traits, the inclusion of reproductive traits for selection purposes is essential to improve the production system (Toelle \& Robison, 1985).
Selection for sexual precocity may have advantages, such as an increase in the stocking rate to slaughter, length of the productive life of cows and rate of genetic progress through a reduction in the generation interval and dilution of heifer-rearing costs, with a consequent marked gain in company revenue. 
Direct selection for female sexual precocity traits is not an easy task because identification of the onset of puberty in heifers is complex, requiring different management for the detection of the first ovulation, for example, the use of teaser bulls or hormone measurement, with consequent additional costs to the production systems. The use of indicator traits for sexual precocity that can be easily measured and that present a favorable correlation with reproductive traits in females seems to be a more feasible alternative to solve this problem.

In an attempt to provide a more accessible measure of precocity to all breeders, Atencio (2000) suggested a new approach to the study of sexual precocity in Zebu females. This method would replace the continuous variable age at first calving with a discrete variable, i.e., probability of early pregnancy (PEP). This approach considers that all females born in a beef herd, in principle, will be destined to become replacement heifers. If this were not observed, the reason would be previous selection (natural or not) intuitively based on reproductive criteria. When age at first calving is included in the evaluation of sexual precocity, only a part of the females born is incorporated into the rearing herd and produces descendants. During this process, a good part of the genetic variability in this trait between individuals is disregarded. Finally, since only a group of females that effectively bred is evaluated, only a small portion of total variability is measured, i.e., the portion that remained within the selected stratum. According to the procedure proposed by Atencio (2000), all weaned females become part of the sample analyzed. A score of 1 is attributed to heifers that effectively enter the herd and a score of 0 to heifers discarded during the period.

The objective of this study was to estimate heritabilities of PEP and scrotal circumference (SC) and the genetic correlation between these traits in Nellore animals.

\section{Material and Methods}

The data used for the study of PEP and SC were obtained from the zootechnical archive of Agropecuária Jacarezinho Ltda., Municipality of Valparaíso, northwestern region of the State of São Paulo, and corresponded to Nellore animals born between 1983 and 2002. Reproductive management consisted of two breeding seasons: spring/ summer (regular or conventional season) starting in the second half of November and lasting 70 days. During this season, all lactating cows, 26-month-old heifers that did not become pregnant during the fall season and 19-20-monthold heifers born to females that became pregnant at 17 months were inseminated. The fall breeding season (anticipated season), which was introduced at the beginning of the 1990s, comprises the period between April and May and lasts for 60 days. During this period, 17-18-month-old heifers were submitted to natural breeding because of the difficulty to detect the heat in heifers of this age.

Assessment at weaning and at about 540 days (yearling) consisted of weighing the animals after a minimum fast of 12 hours, height measurement and visual inspection. The $\mathrm{SC}$ was also measured in all males at yearling age. A weaning index was thus obtained. The traits included in the weaning index were weighted as follows: days to gain $160 \mathrm{~kg}$ from birth to weaning (60\%), conformation ( $8 \%$ ), precocity (16\%), and muscularity (16\%).

The animals were then classified into deciles according to the result of the weaning index. Deciles ranged from 1 to 10 in such a way that animals classified as decile 1 included the superior $10 \%$ of that production season and those classified as decile 10 the inferior $10 \%$ of that production season. Females classified as deciles 1 to 9 were maintained in the herd and those classified as decile 10 were discarded. All heifers were then submitted to reproduction and those that failed to conceive were discarded after the diagnosis of gestation.

Females were selected according to fertility and nonpregnant females were discarded after gestation diagnosis, and according to maternal ability evaluated after weaning.

The PEP trait refers to the observation of whether the born and weaned female remained in the herd for breeding. This trait is indicative of sexual precocity since the reason for the female not to remain in the herd is the occurrence of previous selection (natural or not) intuitively based on reproductive criteria. This variable presents discrete variation since females that effectively enter the herd receive a score of 1 and those that are discarded receive a score of 0 .

Since the age of the animal influences $\mathrm{SC}$, this parameter was adjusted according to age. SC was previously adjusted to 530 days of age, the average age observed in this herd. Subsequently, a quadratic-quadratic segmented polynomial with a knot at 574 days was used to model this effect. The curve corresponding to the segmented polynomial was constructed by the least square method using the REG procedure of the SAS software (SAS, 2002). The SC correction factor according to age was calculated as follows:

$$
\mathrm{CF}=\mathrm{X}_{\text {base }} / \mathrm{X}_{\mathrm{c}}
$$

where $\mathrm{CF}=$ correction factor; $\mathrm{X}_{\text {base }}=\mathrm{SC}(26.82 \mathrm{~cm}$ at 530 days) estimated at baseline, and $\mathrm{X}_{\mathrm{c}}=\mathrm{SC}$ predicted by the segmented polynomial function.

After determining the consistency of the data, the PEP file contained 11,696 records of females, daughters of 253 
sires. The contemporary group consisted of animals born in the same year and season that belonged to the same farm, management group at birth and weaning, and type of service to which the dam of the calf was submitted (artificial insemination, controlled or uncontrolled natural breeding), forming a total of 458 contemporary groups. For males, the type of service was excluded and management group at yearling was included, for a total of 415 contemporary groups. The SC file contained 9335 records of animals born to 224 sires. The birth season was classified according to the period of the year, with animals born between January and June being allocated to season 1 and animals born between July and December to season 2 .

The degree of connectability of the data between different contemporary groups was determined with the MILC software (Matriz de Incidência, Laços Genéticos e Conectabilidade) developed by Fries \& Roso (1997). This program determines the number of direct genetic links between contemporary groups by means of sires and cows with progeny in these groups. Thus, a direct genetic link exists between one contemporary group and another when there is one sire (or cow) with at least one controlled progeny in each of these groups.

A posteriori distributions of covariance components and heritability estimates for PEP and SC and the genetic correlation between these traits were obtained by Gibbs sampling using the threshold version of the MTGSAM program (Multiple Trait Gibbs Sampling in Animal Models; Van Tassel \& Van Vleck, 1995).

In principle, genetic variances were estimated using an animal model that included the direct genetic effects of the animal, maternal genetic effects, permanent environmental effects of the heifer mother, and contemporary group. However, when this model was used, the iterations were terminated before reaching the established convergence criterion and the additive genetic variance estimates of the samples always increased. This difficulty has been reported for the use of threshold models when the fixed effects presented numerous levels (Moreno et al., 1997; Phocas \& Laloë, 2003; Mattar et al., 2007). The implementation of Markov chains or MCMC (including Gibbs sampling) solves part of this problem but generates another: convergence of the chains is not always possible and generally only occurs when the data present a normal distribution (Blasco, 2001). A sire model was thus adopted after attempts of convergence using an animal model had failed to concentrate the observations of traits in a smaller number of animals and to permit convergence of the analyses.

A threshold model was used for PEP, in which the response observed on a categorical scale is related to a normal continuous underlying scale with normal distribution (Silva et al., 2003b):

$$
\mathrm{U} \mathrm{I} \theta \sim \mathrm{N}\left(\mathrm{W} \theta^{\prime}, \mathrm{I} \sigma_{\mathrm{e}}^{2}\right)
$$

where $\mathrm{U}=$ vector of the underlying scale of order $\mathrm{r}$; $\theta^{\prime}=\left(E F{ }^{\prime}, a^{\prime}\right)=$ vector of location parameters of order s, with EF being defined by the frequentist approach as fixed effects and $a$ as random effects; $\mathrm{W}=$ known incidence matrix of order $\mathrm{r} \times \mathrm{s}$; I $=$ identity matrix of order $\mathrm{r} \times \mathrm{r}$; $\sigma_{\mathrm{e}}^{2}=$ residual variance.

Assuming that initial distributions for genetic and residual effects follow a normal multivariate distribution, we have:

$$
\begin{aligned}
& \mathrm{P}\left(\mathrm{a} \mid \sigma_{\mathrm{a}}^{2}\right) \sim \mathrm{N}\left(0, \mathrm{~A} \sigma_{\mathrm{a}}^{2}\right) \\
& \mathrm{P}\left(\mathrm{e} \mid \sigma_{\mathrm{e}}^{2}\right) \sim \mathrm{N}\left(0, \mathrm{I} \sigma_{\mathrm{e}}^{2}\right)
\end{aligned}
$$

where $\sigma_{\mathrm{a}}^{2}$ corresponds to additive genetic variance.

Since residual variance $\left(\sigma_{\mathrm{e}}^{2}\right)$ cannot be estimated, Gianola \& Foulley (1983) suggested to attribute a value of 1 to this parameter $\left(\sigma_{\mathrm{e}}^{2}=1\right)$.

A priori data were defined as flat or non-informative distributions (so that they did not reflect previous knowledge about the parameter) for ( $b^{\prime}=E F$ ') effects and for $\sigma_{\mathrm{a}}^{2}$. This type of a priori distribution is expected to provide dominant data, i.e., previous information has little influence on the estimates.

PEP and SC were analyzed to determine the existence of an association between these traits. For PEP, the statistical model included the effects of contemporary group, age of dam at calving and heifer weaning age (Table 1), and sire and residual effects. SC was analyzed using a linear model including the effects of contemporary group and sire and residual effects. Residual covariance was assumed to be zero since the measures analyzed were obtained from different animals (females and males).

The statistical model used for PEP and SC was:

$$
\mathrm{y}=\mathrm{X} \beta+\mathrm{Zu}+\mathrm{e}
$$

where $y=$ vector of observations; $X=$ incidence matrix of the effects of contemporary group, age of dam at calving

Table 1 - Age of dam at calving and weaning age of Nellore heifers

\begin{tabular}{lc}
\hline Class & Age of dam at calving (years) \\
\hline 1 & $2-3$ \\
2 & $4-6$ \\
3 & $7-9$ \\
& Weaning age of heifer (months) \\
1 & $4-6$ \\
2 & $6-6.5$ \\
3 & $6.6-7$ \\
4 & $>7$ \\
\hline
\end{tabular}


and weaning age for females and incidence matrix of the effects of contemporary group for males; $\beta=$ vector of fixed effects; $Z=$ matrix associating each sire to observations of its progeny; $u=$ vector of sire effect, and $\mathrm{e}=$ vector of residual random errors associated with the observations.

On the basis of preliminary analyses performed with the Gibanal program developed by Van Kaam (1998), the burn-in period was 2000 initial vectors and the sampling frequency was 152 . The effective sample size was 1494 , resulting in a Markov chain length of 53,088 for later calculation of heritability estimates.

The Geweke test (Geweke, 1992) was used to determine the convergence of the Markov chains.

The credibility region used in Bayesian analysis consisted of the elimination of the 5\% lowest and 5\% highest a posteriori distributions of the parameters.

The covariance components were estimated using the following formulas:

$\sigma_{\mathrm{a} P E P}^{2}=\left(4 * \sigma_{\mathrm{a} \text { PEP-sire }}^{2}\right) ;$

$\left.\mathrm{h}_{\text {PEP }}^{2}=\left(\sigma_{\mathrm{a} \text { PEP }}^{2}\right) /\left(\sigma_{\mathrm{a} \text { PEP }}^{2}\right)+\sigma_{\mathrm{e} \text { PEP }}^{2}\right) ;$

$\sigma_{\mathrm{a} S C}^{2}=\left(4 * \sigma_{\mathrm{a} S C-\text { sire }}^{2}\right)$;

$\mathrm{h}_{\mathrm{SC}}^{2}=\sigma_{\mathrm{a} S \mathrm{C}}^{2}\left(\sigma_{\mathrm{a} \mathrm{SC}}^{2}+\mathrm{S}_{\mathrm{e} S \mathrm{SC}}^{2}\right)$;

$r_{\text {PEP-SC }}=\operatorname{Cov}_{\text {PEP-SC }} /\left(\operatorname{sqrt}\left(\sigma_{\text {a PEP }}^{2}\right)\right) *\left(\operatorname{sqrt}\left(\sigma_{\text {a SC }}^{2}\right)\right)$;

where $\sigma_{\mathrm{a}}^{2}$ and $\sigma_{\mathrm{e}}^{2}$ =variances of direct additive genetic and residual effects for the traits studied, respectively; $\mathrm{h}^{2}=$ heritability of the trait; $\mathrm{Cov}=$ covariance between direct genetic effects of PEP and SC, and $\mathrm{r}_{\mathrm{PEP}-\mathrm{SC}}=$ correlation between the direct additive genetic effects of PEP and SC.

\section{Results and Discussion}

In the present study, $19.84 \%$ of females received a score of 1 for PEP, i.e., these females remained in the herd. The management established on the farm guaranteed that females classified as deciles 1 to 9 had the chance to reproduce and were discarded if they did not become pregnant. A value higher than that observed in this study was reported by Mattar et al. (2007) who reported a percentage of $46 \%$ of animals with a score of 1 for PEP. However, the latter study involved Caracu animals, a breed of European origin.

The mean SC observed was $27.06 \pm 3.10 \mathrm{~cm}$, an estimate higher than the $25.55 \mathrm{~cm}$ reported by Ortiz Peña et al. (2001) also for Nellore animals. This result might be explained by the fact that in the present herd selection for sexual precocity has been performed for several years using $\mathrm{SC}$ as a criterion.
Mean heritability $\left(\mathrm{h}^{2}\right)$ and its respective standard error were $0.47 \pm 0.05$ for PEP and $0.27 \pm 0.03$ for SC (Table 2). The heritability estimate obtained for PEP was high, indicating that a large part of the variation in PEP was due to direct additive genetic effects, i.e., this trait may respond to selection. The heritability for SC observed here was lower than the estimates reported by Ortiz Peña et al. (2001) and Silva et al. (2002), who also studied Nellore animals and obtained values of 0.40 and 0.44 , respectively.

Convergence was achieved as indicated by a $\mathrm{Z}$ score of 0.2024 in the Geweke test (Geweke, 1992) (Figures 1 and 2). According to Blasco et al. (2003), Z scores in the Geweke test ranging from $-1.96<\mathrm{Z}<1.96$ indicate that convergence was achieved.

Mean, median and mode heritability of the genetic parameters was the same (Table 2), a finding confirmed by the observation of marginal posterior distributions (Figures 1 and 2).

The columns containing a larger number of subsamples of the estimates comprised the mean and median heritability detected (Figures 1 and 2), a finding suggesting reliability in the mean estimates obtained.

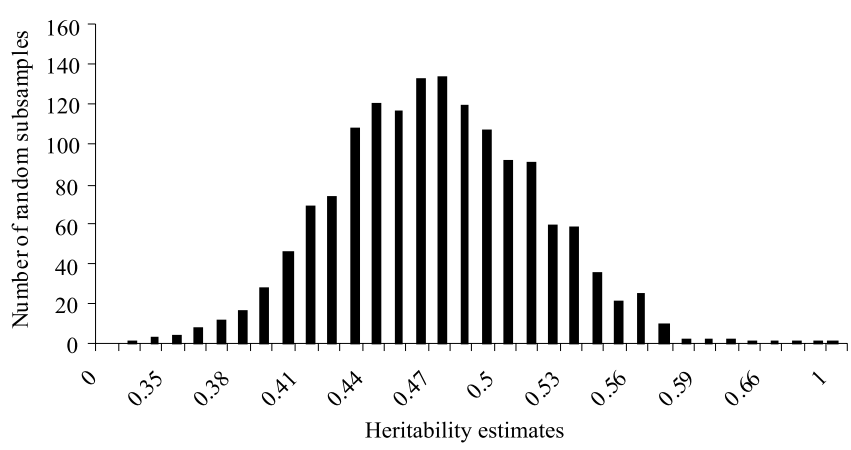

Figure 1 - Frequency of heritability estimates for probability of early pregnancy (PEP) in Nellore heifers.

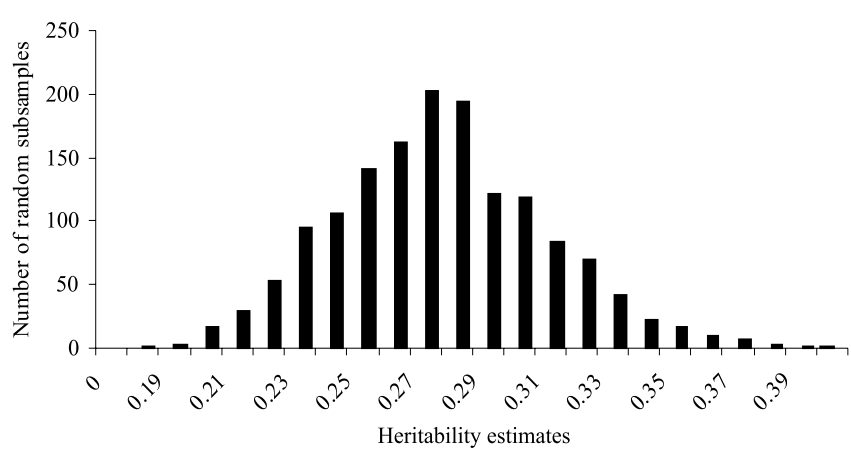

Figure 2 - Frequency of heritability estimates for scrotal circumference (SC) in Nellore males. 
Table 2 - Estimates of mean, standard error of the mean, mode and median heritability and $95 \%$ credibility region for probability of early pregnancy (PEP) and scrotal circumference (SC) in Nellore cattle

\begin{tabular}{lccccc}
\hline Trait & $\begin{array}{c}\text { Mean } \\
\text { heritability }\end{array}$ & $\begin{array}{c}\text { Standard } \\
\text { error }\end{array}$ & Mode & Median & $95 \%$ CR \\
\hline PEP & 0.47 & 0.05 & 0.47 & 0.47 & $0.38-0.56$ \\
SC & 0.27 & 0.03 & 0.27 & 0.27 & $0.21-0.34$ \\
\hline
\end{tabular}

95\% CR : $95 \%$ credibility region

The $95 \%$ credibility regions of the heritability estimates for PEP and SC (Table 2) showed small amplitudes of variation, demonstrating that the mean estimates obtained for these parameters were good indicators of the true values of the parameters in the population studied.

Eler et al. (2002a) studied Nellore heifers using a single-trait animal model and estimated a heritability of $0.57 \pm 0.01$ for probability of pregnancy at 14 months (PP14). In another study using the same data set and a sire model, Silva et al. (2003a) estimated a heritability of $0.73 \pm 0.01$ for PP14. The authors explained this high value by the use of a sire model since this procedure does not include the maternal relationship (maternal genetic merit) and additive genetic variance was estimated only on the basis of sires and their descendants. Similarly, Silva et al. (2002) estimated covariance components by Bayesian inference and also found a high heritability of 0.81 for PP14 in Nellore heifers. Since PP14 was processed as a threshold trait using an underlying scale, the authors employed the Dempster \& Lerner (1950) to obtain heritabilities on the observed scale, with the estimate decreasing to 0.41 . The authors showed that fertility-related traits do not always present low heritability because they depend on how they are measured and analyzed.

A lower heritability of 0.13 for PEP was reported by Mattar et al. (2007) who used data from Caracu animals and Bayesian inference in a sire model. According to these authors, the small magnitude of the estimate might be a reflection of the breed formation process itself, which originated from random mating of different European breeds. These factors, together with natural selection, favored animals of better reproductive performance and more adapted to tropical conditions, resulting in sexually more precocious animals which, therefore, presented lower genetic variability for age at puberty.

In the present study, the estimate of genetic correlation between PEP and SC was $0.12 \pm 0.20$, indicating that the two traits shared some genes that exert an additive effect. The estimated correlation indicated a small, but favorable, association between the two traits. According to Eler et al. (2002b), SC has been employed as a selection criterion for sexual precocity over many years and breeding programs possess a large amount of information for this trait. Taking advantage of this information available in the databank, $\mathrm{SC}$ can be used together with PEP in genetic evaluations to improve the accuracy of prediction of expected progeny differences for PEP. However, the high standard error of the estimated genetic correlation between PEP and SC observed in this study indicated that this correlation is not very reliable for use in genetic predictions and may only serve as a weak indicator of a genetic association between the two traits.

Although not studying the same trait, Silva et al. (2002) observed a higher genetic correlation between PP14 and SC adjusted for 450 days $(0.46 \pm 0.10)$. Comparison of PEP and PP14 showed that the latter trait was interesting as a selection criterion for female sexual precocity. However, this trait depends on management systems still applied in a limited manner that permit the exposure of females to sires at 12-16 months of age, whereas PEP can be applied to all herds for which collected (recorded) information is available.

\section{Conclusions}

The prediction of genetic merit for PEP might be used to improve heifer fertility without increasing the production costs of the herd. The main advantage of using PEP as a measure of female sexual precocity is the inclusion of all females born (or weaned) in the genetic evaluation, a fact that permits the maintenance of genetic variability between individuals. The use of $\mathrm{SC}$ as a selection criterion for female sexual precocity would have a small effect on the response to selection.

\section{Acknowledgements}

The authors thank Agropecuária Jacarezinho for providing the data, and professor Joanir Pereira Eler (FZEA, USP, Pirassununga) for help with the analyses.

\section{Literature Cited}

ATENCIO, A.M. Predicción genética de la fertilidad en la hembra cebu. In: CONGRESSO INTERNACIONAL CEA, 20., 2000, Asunción. Anales... Asunción: CEA, 2000. p.29-42.

BLASCO, A. The Bayesian controversy in animal breeding. Journal of Animal Science, v.79, p.2023-2046, 2001.

BLASCO, A.; PILES, M.; VARONA, L. A Bayesian analysis of the effect of selection for growth rate on growth curves in rabbits. Genetics Selection Evolution, v.35, p.21-41, 2003.

DEMPSTER, E.R.; LERNER, I.M. Heritability of threshold characters. Genetics, v.35, p.212, 1950. 
ELER, J.P.; SILVA, J.A.II.V.; FERRAZ, J.B.S. et al. Genetic evaluation of the probability of pregnancy at 14 months for Nellore heifers. Journal of Animal Science, v.80, n.3, p.951-954, 2002a.

ELER, J.P.; DIAS, F.; FERRAZ, J.B.S. Precocidade sexual em zebuínos - do mito à realidade. In: CONGRESSO BRASILEIRO DAS RAÇAS ZEBUÍNAS, 5., 2002, Uberaba. Anais... Uberaba: Associação Brasileira de Criadores de Zebu, 2002b. p.205-211.

FRIES, L.A.; ROSO, V.M. Conectabilidade em avaliações genéticas de gado de corte: uma proposta heurística. In: REUNIÃO ANUAL DA SOCIEDADE BRASILEIRA DE ZOOTECNIA, 34., 1997, Juiz de Fora. Anais... Juiz de Fora: Sociedade Brasileira de Zootecnia, 1997. p.159-161.

GEWEKE, J. Evaluating the accuracy of sampling-based approaches to the calculation of posterior moments (with discussion). In: BERNARDO, J.M.; BERGER, J.O.; DAWID, A.P. et al. (Eds.) Bayesian Statistics. Oxford: University Press, 1992. p.169-193.

GIANOLA, D.; FOULLEY, J.L. Sire evaluation for ordered categorical data with a threshold model. Genetics Selection Evolution, v.15, p.201-224, 1983.

MATTAR, M.; OLIVEIRA, J.A. MEIRELLES, S.L. et al. Efeitos genéticos e ambientais sobre o perímetro escrotal de animais da raça Caracu. Revista Brasileira de Zootecnia, v.36, n.6, p.2010-2015, 2007.

MORENO, C.; SORENSEN, D.; GARCIA-CORTÉS, L.A. et al. On biased inferences about variance components in the binary threshold model. Genetics Selection Evolution, v.29, p.145-160, 1997.

ORTIZ PEÑA, C.D.; QUEIROZ, S.A.; FRIES, L.A. Comparação entre critérios de seleção de precocidade sexual e a associação destes com características de crescimento em bovinos Nelore. Revista Brasileira de Zootecnia, v.30, n.1, p.93-100, 2001.
PHOCAS, F.; LALOË, D. Evaluation models and genetic parameters for calving difficulty in beef cattle. Journal of Animal Science, v.81, p.933-938, 2003.

SILVA, J.A.II.V.; OLIVEIRA, H.N.; ELER, J.P. et al. Parâmetros genéticos de prenhez de novilhas aos 14 meses e de perímetro escrotal de machos Nelore usando Inferência Bayesiana. In: SIMPÓSIO NACIONAL DE MELHORAMENTO ANIMAL, 2002, Campo Grande. Anais eletrônicos... Campo Grande: SBMA, 2002. Disponível em: <http.www.cnpgc.embrapa.br/ sbma>. Acesso em 20/10/2002.

SILVA, J.A.II,V.; MELIS, M.H.V.; ELER, J.P. et al. Estimação de parâmetros genéticos para probabilidade de prenhez aos 14 meses e altura na garupa em bovinos da raça Nelore. Revista Brasileira de Zootecnia, v.32, n.5, p.1141-1146, 2003 a.

SILVA, J.A.II V.; ELER, J.P.; OLIVEIRA, H.N. et al. Análise genética da habilidade de permanência em fêmeas da raça Nelore. Revista Brasileira de Zootecnia, v.32, n.3, p.598-604, 2003b.

STATISTICAL ANALYSIS SYSTEM - SAS. SAS/STAT, user's guide, version 6.12. 4.ed. Cary: SAS Institute, 2002. 842p.

TOELLE, V.D.; ROBISON, O.W. Estimates of genetic correlations between testicular measurements and female reproductive traits in cattle. Journal of Animal Science, v.60, n.1, p.89-100, 1985.

Van KAAM, J.B.C.H.M. "GIBANAL" - Analyzing program for Markov Chain Monte Carlo Sequences (Version 2.10). Wageningen: Department of Animal Sciences, Wageningen Agricultural University, 1998. 86p.

Van TASSELL, C.P.; Van VLECK, D.L. A manual for use of MTGSAM. A set of FORTRAN programs to apply Gibbs sampling to animal models for variance component estimation [DRAFT]. Lincoln: U.S. Department of Agriculture, Agricultural Research Service, 1995. 86p. 